Original Research Paper

\title{
Evaluation of the Digestibility of Various Types of Swamp Grass in South Sumatra on Pampangan Local Buffalo using the in Sacco Method
}

\author{
1*Armina Fariani, ${ }^{1}$ Gatot Muslim, ${ }^{1}$ Anggriawan N.T. Pratama and ${ }^{2}$ Lili Warly \\ ${ }^{I}$ Department of Animal Science, Agriculture Faculty, Universitas Sriwijaya, Sumatera Selatan, Indonesia \\ ${ }^{2}$ Faculty of Animal Husbandry andalas University, Padang, Indonesia
}

\author{
Article history \\ Received: 19-05-2021 \\ Revised: 24-06-2021 \\ Accepted: 27-07-2021 \\ Corresponding Author: \\ Armina Fariani \\ Animal Science Department, \\ Agriculture Faculty, \\ Universitas Sriwijaya, \\ Sumatera Selatan, Indonesia \\ Email: arminafariani@unsri.ac.id
}

\begin{abstract}
This study aims to determine the digestibility value and degradation rate of various types of swamp grass in Sacco in local Pampangan buffalo in South Sumatra. The design used in the study was a completely randomized design consisting of 6 treatments and three replications. The treatments tested were six types of swamp grass which were then coded for each treatment as follows: Hymenachne Acutigluma (HA1), Hymenachne Amplexicaulis (HA2), Oryza Rufipogon (OR), Rhynchospora Corymbose (RC), Eleocharis Dulcis (ED) and Leersia Hexandra (LH). The observed variables in this study were degradation rate and Analysis of fiber fraction content in each grass includes Neutral Detergent Fiber (NDF), Acid Detergent Fiber (ADF), Hemicellulose and Cellulose. The results showed that ED grass had the highest total digestibility value for each fiber fraction variable. The rate of degradation shows an interesting pattern where Overall, the value of fractions $a, b$ and $c$ for each observation parameter showed a significant difference $(\mathrm{P}<0.05)$. Based on this study, it can be concluded that ED grass has the best fiber digestibility than other types of swamp grass and is very potential for buffalo livestock due to its high degradation rate.
\end{abstract}

Keywords: Swamp Grass, Pampangan Buffalo, In Sacco

\section{Introduction}

A feed is an essential component that is the key to livestock cultivation, ruminants and other livestock. Feed plays a vital role in livestock cultivation because it affects growing, developing and producing. Ruminants require large amounts of feed, mainly forage. Forage is a staple feed that ruminants must consume, which functions as a source of nutrition and a source of fiber. Feed must be very concerned about the availability of adequate forage, both quantity, quality and the presence of limiting factors such as lignin, which can reduce livestock productivity (Oliveira et al., 2020). The availability of land influences the availability of forage to produce forage. Limited land for forage production due to the conversion of land use to housing and industry has reduced the production of forage as a sustainable animal feed.
Many swamps land in Indonesia have considerable potential to provide forage for livestock and be a solution to limited forage. The abundance of various swamp grasses such as Kumpai (Hymenachne) and legumes can be used as natural feed ingredients for ruminants, especially swamp buffalo, where their natural habitat is in swamp areas (Rostini and Jaelani, 2015). Some dominant vegetation types grow and develop in swamplands. Between them like grass Kumpai Tembaga (Hymenachne acutigluma), Kumpai Minyak (Hymenachne amplexicaulis), Kumpai Padi (Oryza rufipogon), Sendayan (Rhynchospora corymbose), Purun Tikus (Eleocharis dulcis), dan Bento Rayap (Leersia hexandra).

This type of swampy forage is generally very popular with ruminants. However, in its utilization, ruminants use swampy forage as the main feed, namely buffalo. Because the swampy forage grows and develops during the rainy season with a high puddle of water, so getting the forage livestock has to swim and 
dive in the swamp. In these circumstances, buffalo livestock is very potential compared to other ruminants because they have high suitability and adaptability in the ecosystem or habitat. Furthermore, in addition to these advantages, buffalo livestock also has other benefits: Having rumen microbes dominated by these higher fiber digesting microbes (Dadheech et al., 2018; Iqbal et al., 2018; Jaglan et al., 2019). because most types of swampy forages contain a high fiber fraction, so they require better digestibility than ruminants in general (Fariani and Evitayani, 2008).

Based on the description above in this study, the investigation was carried out on the digestibility values and digestibility rates of several swamp forage types using the in Sacco method. It is hoped that the information obtained in this study can provide information on the digestibility value and rate of swamp forage types so that it can provide recommendations for the utilization of various kinds of swamp forage.

\section{Materials and Methods}

\section{Sample Collection and Processing}

Grass samples were taken during the rainy season (March 2019) in the Pampangan Ogan Komering Ilir sub-district and Banyuasin sub-district, South Sumatra. The swamp grass samples taken included Kumpai Tembaga grass (Hymenachne acutigluma), Kumpai Minyak (Hymenachne amplexicaulis), Kumpai Padi (Oryza rufipogon), Sendayan (Rhynchospora corymbose), Purun Tikus (Eleocharis dulcis) and Termite Bento (Leersia hexandra). All grass types are taken at the same age/stage, namely at the blooming stage, dried in the hot sun, milled to a size of $1 \mathrm{~mm}$ following the filter requirements for nylon bags (Orskov et al., 1980). The composition of the fiber fraction contained in each type of grass can be seen in Table 1.

\section{Experimental Design, Livestock and Diet}

The design used in the study was a completely randomized design consisting of 6 treatments and three replications. The treatments tested were six types of swamp grass which were then coded for each treatment as follows: Hymenachne Acutigluma (HA1), Hymenachne Amplexicaulis (HA2), Oryza Rufipogon (OR), Rhynchospora Corymbose (RC), Eleocharis Dulcis (ED) and Leersia Hexandra (LH). Meanwhile, the three replications were used to reflect the number of samples and buffalo used in the Sacco experiment. The buffalo used in this study were three female buffalo two-year-old with an average weight of $200 \mathrm{~kg}$. The cattle are placed in a closed outdoor enclosure $\left(3 \mathrm{~m}^{2}\right)$ equipped with a cannula. They are given food consisting of odot grass that has been previously harvested in the laboratory of the Sriwijaya University experimental cage. Buffalo was fed ad libitum to odot grass, trace minerals and water during the experiment. This phase was carried out for two weeks before the study was carried out.

\section{Rumen Digestibility (in Sacco Technique)}

The in Sacco method used in this study is based on the ILCA manual book feed evaluation. It is using five $\times 10 \mathrm{~cm}$ nylon bags with a porosity of $50 \pm 15$. A total of 3 grams of forage samples were weighed and placed into a nylon bag that had previously been considered. Each type of grass had three replications and was incubated for 0 , $6,12,24,36$ and $48 \mathrm{~h}$ in the buffalo rumen. So that in each cannula, there are five pockets. The nylon bags have been removed according to a predetermined time, are sorted according to grass type, washed in running water and stored at $-20^{\circ} \mathrm{C}$ until all grass species have been incubated. After all the grass has been successfully incubated, the stored samples are thawed at $65^{\circ} \mathrm{C}$ until dry and then weighed.

\section{Chemical Analysis and Calculations}

Analysis of fiber fraction content in each grass includes Neutral Detergent Fiber (NDF), Acid Detergent Fiber (ADF), Hemicellulose, Cellulose and Lignin based on the Van Soest (1988). The analysis results are divided into two parts, namely before and after the incubation period.

Table 1: Swamp grass fiber composition

\begin{tabular}{|c|c|c|c|c|c|c|}
\hline \multirow[b]{2}{*}{ Fiber Fraction $(\%)$} & \multicolumn{6}{|c|}{ Type of forages } \\
\hline & HA1 & HA2 & OR & $\mathrm{RC}$ & ED & LH \\
\hline NDF & 74,9 & 68,8 & 57,4 & 64,6 & 84,8 & 77,9 \\
\hline $\mathrm{ADF}$ & 40,9 & 40,0 & 28,9 & 36,4 & 70,9 & 41,9 \\
\hline Hemicellulose & 34,0 & 28,7 & 28,5 & 28,2 & 13,8 & 36,0 \\
\hline cellulose & 39,1 & 37,6 & 28,5 & 35,1 & 59,3 & 33,4 \\
\hline Lignin & 1,80 & 2,42 & 8,55 & 1,35 & 1,63 & 1,73 \\
\hline
\end{tabular}

Note: Neutral Detergent Fiber (NDF); Acid Detergent Fiber (ADF) 
The fiber fraction difference is assumed to be part of the digested/lost fraction value during the incubation process. As for the calculation of the loss in fiber fraction value based on the ILCA method with the following formula:

Disappearance $=\frac{(S W a-B W) \times D M a-(S W b-B W) \times D M b}{(S W a B W) \times D M a}$

Where:

$S W a=$ Weight of the original sample + nylon bag

$B W=$ Weight of empty nylon bag

$S W b=$ Weight of the sample + nylon bag after incubation

$D M a=$ Dry matter of feed sample

$D M b=$ Dry matter of residue sample

The value in the formula used in dry matter is then adjusted to the value of the fiber fraction used as the research parameter. Furthermore, to calculate the fraction degradation rate $(\mathrm{kd})$ of NDF (kd-NDF), ADF (kd-ADF), Hemicellulose $(\mathrm{kd}-\mathrm{H})$ and Cellulose $(\mathrm{kd}-\mathrm{C})$ were calculated according to the calculation model Ørskov and McDonald (1979):

$$
Y=a+b\left(1-e^{-c t}\right)
$$

where, $Y=$ degradability at time (t), $a=$ intercept/dissolved fraction, $b=$ potentially degradable fraction and $c=$ rate of degradation of $b$. The Analysis was performed using the curve fit program excel solver.

\section{Data Analysis}

Data were analyzed using a randomized block design; if there is a difference between treatments, the Duncan Multi Range Test (DNMRT) further test is carried out (Steel and Torrie, 1980).

\section{Results}

\section{Total Digestibility}

The total digestibility values during the $6-48 \mathrm{~h}$ incubation period obtained during the study using the Orskov method can be seen in Table 2. Overall, the study results showed significant differences between treatments $(\mathrm{P}<0.05)$ on the digestibility values of NDF, ADF, Hemicellulose and Cellulose. The highest digestibility value in all observed parameters was found in ED treatment, significantly different from other treatments $(\mathrm{P}<0.05)$. At the NDF digestibility value, the HA1 treatment had the lowest value and was not different from the RC treatment $(\mathrm{P}>0.05)$. However, it differed significantly from the LH treatment $\quad(\mathrm{P}<0.05)$. Furthermore, a significant difference was shown in the OR treatment compared to the LH treatment $(\mathrm{P}<0.05)$ but not different when compared to the HA2 treatment $(\mathrm{P}>0.05)$. Almost the same pattern was shown in the ADF digestibility value, where the difference in the pattern only occurred in the RC treatment, which was not significantly different from the LH treatment $(\mathrm{P}>0.05)$ and the HA2 treatment, which showed a significant difference compared to the OR treatment $(\mathrm{P}<0.05)$. Meanwhile, hemicellulose values a different pattern was shown in the RC treatment, where it had a higher value than the HA1, HA2 and LH treatment $(\mathrm{P}<0.05)$ but did not differ from the OR treatment $(\mathrm{P}>0.05)$. Furthermore, the cellulose digestibility values showed a significant difference in HA2 treatment compared to HA1 and LH treatment $(\mathrm{P}<0.05)$ but not significantly different from the $\mathrm{OR}$ and $\mathrm{RC}$ treatment $(\mathrm{P}>0.05)$.

\section{Fiber Fraction Degradation Pattern}

The analysis results show that the degradation pattern in each fraction is dominated by different types of grass, as shown in Table 3. In contrast, the description of the degradation pattern based on the incubation time can be seen in Fig. 1 - 4. Overall, the value of fractions $a, b$ and c for each observation parameter showed a significant difference $(\mathrm{P}<0.05)$ infraction, reflecting the easily dissolved fraction in feed ingredients. The observation of NDF, ADF, hemicellulose and cellulose is dominated by LH grass. In contrast, in infraction b, a degradation potential/slow dissolution is dominated by OR grass. However, the fraction $\mathrm{c}$, which reflected the degradation rate, the dominance was not found in LH or OR grass but was found in ED grass.

Table 2: Digestibility of total swamp grass fiber fraction

\begin{tabular}{|c|c|c|c|c|}
\hline \multirow[b]{2}{*}{ Type of forages } & \multicolumn{4}{|c|}{ Fiber fraction } \\
\hline & NDF & $\mathrm{ADF}$ & Hemicellulose & Cellulose \\
\hline Hymenachne Acutigluma (HA1) & $41,67^{\mathrm{a}}$ & $41,34^{\mathrm{a}}$ & $42,08^{\mathrm{a}}$ & $40,03^{\mathrm{a}}$ \\
\hline Hymenachne Amplexicaulis (HA2) & $54,70^{\mathrm{c}}$ & $46,66^{\mathrm{c}}$ & $58,71^{\mathrm{c}}$ & $48,28^{c}$ \\
\hline Oryza Rufipogon (OR) & $53,66^{\mathrm{c}}$ & $57,96^{\mathrm{d}}$ & $60,59^{\mathrm{cd}}$ & $46,38^{b c}$ \\
\hline Rhynchospora Corymbosa (RC) & $42,48^{\mathrm{a}}$ & $43,00^{\mathrm{ab}}$ & $64,00^{\mathrm{d}}$ & $47,42^{\mathrm{bc}}$ \\
\hline Eleocharis Dulcis (ED) & $64,12^{\mathrm{d}}$ & $63,01^{\mathrm{e}}$ & $66,61^{\mathrm{e}}$ & $61,23^{\mathrm{d}}$ \\
\hline Leersia Hexandra $(\mathrm{LH})$ & $45,82^{\mathrm{b}}$ & $44,18^{\mathrm{b}}$ & $47,71^{\mathrm{b}}$ & $44,22^{\mathrm{b}}$ \\
\hline
\end{tabular}

Note: Neutral Detergent Fiber (NDF); Acid Detergent Fiber (ADF) 
Armina Fariani et al. / American Journal of Animal and Veterinary Sciences 2021, 16 (3): 152.160 DOI: 10.3844/ajavsp.2021.152.160

Table 3: The rate of degradation of the swamp grass fiber fraction

\begin{tabular}{|c|c|c|c|}
\hline \multirow{2}{*}{$\begin{array}{l}\text { Type of forage } \\
\text { (kd-NDF) }\end{array}$} & \multicolumn{3}{|c|}{ Fiber fraction } \\
\hline & a $(\%)$ & $\mathrm{b}(\%)$ & $\mathrm{c}(\% /$ hour $)$ \\
\hline Hymenachne Acutigluma (HA1) & $27,33^{\mathrm{c}}$ & $27,33^{\mathrm{a}}$ & $0,08^{\mathrm{a}}$ \\
\hline Oryza Rufipogon (OR) & $18,64^{\mathrm{a}}$ & $54,91^{\mathrm{e}}$ & $0,08^{\mathrm{a}}$ \\
\hline Rhynchospora Corymbosa (RC) & $18,74^{\mathrm{a}}$ & $34,48^{\mathrm{c}}$ & $0,09^{\mathrm{a}}$ \\
\hline Eleocharis Dulcis (ED) & $31,90^{\mathrm{e}}$ & $33,27^{\mathrm{bc}}$ & $0,81^{\mathrm{b}}$ \\
\hline Leersia Hexandra (LH) & $30,22^{\mathrm{d}}$ & $31,26^{\mathrm{b}}$ & $0,08^{\mathrm{a}}$ \\
\hline \multicolumn{4}{|l|}{$\mathrm{kd}-\mathrm{ADF}$} \\
\hline Hymenachne Acutigluma (HA1) & $32,23^{\mathrm{c}}$ & $32,23^{\mathrm{bc}}$ & $0,05^{\mathrm{a}}$ \\
\hline Hymenachne Amplexicaulis (HA2) & $22,01^{\mathrm{a}}$ & $35,82^{\mathrm{c}}$ & $0,10^{\mathrm{a}}$ \\
\hline Oryza Rufipogon (OR) & $19,47^{\mathrm{a}}$ & $62,13^{\mathrm{d}}$ & $0,07^{\mathrm{a}}$ \\
\hline Rhynchospora Corymbosa (RC) & $27,07^{\mathrm{b}}$ & $29,47^{\mathrm{b}}$ & $0,08^{\mathrm{a}}$ \\
\hline Eleocharis Dulcis (ED) & $31,48^{\mathrm{c}}$ & $32,79^{\mathrm{bc}}$ & $0,94^{\mathrm{b}}$ \\
\hline Leersia Hexandra $(\mathrm{LH})$ & $37,98^{d}$ & $23,40^{\mathrm{a}}$ & $0,07^{\mathrm{a}}$ \\
\hline \multicolumn{4}{|l|}{ kd-Hemicellulose } \\
\hline Hymenachne Amplexicaulis (HA2) & $23,95^{\mathrm{ab}}$ & $40,94^{\mathrm{c}}$ & $0,18^{\mathrm{b}}$ \\
\hline Oryza Rufipogon (OR) & $19,93^{\mathrm{a}}$ & $66,68^{d}$ & $0,06^{\mathrm{a}}$ \\
\hline Rhynchospora Corymbosa (RC) & $31,45^{\mathrm{c}}$ & $34,49^{\mathrm{b}}$ & $0,35^{\mathrm{c}}$ \\
\hline Eleocharis Dulcis (ED) & $33,89^{\mathrm{c}}$ & $35,31^{\mathrm{bc}}$ & $0,32^{\mathrm{c}}$ \\
\hline Leersia Hexandra $(\mathrm{LH})$ & $38,60^{\mathrm{d}}$ & $23,64^{\mathrm{a}}$ & $0,08^{\mathrm{a}}$ \\
\hline \multicolumn{4}{|l|}{ kd-Cellulose } \\
\hline Hymenachne Acutigluma (HA1) & $31,32^{\mathrm{d}}$ & $31,32^{\mathrm{b}}$ & 0,05 \\
\hline Hymenachne Amplexicaulis (HA2) & $22,40^{\mathrm{b}}$ & $36,42^{\mathrm{b}}$ & 0,11 \\
\hline Oryza Rufipogon (OR) & $18,75^{\mathrm{a}}$ & $53,10^{\mathrm{c}}$ & 0,06 \\
\hline Rhynchospora Corymbosa (RC) & $28,10^{\mathrm{c}}$ & $30,76^{\mathrm{b}}$ & 0,11 \\
\hline Eleocharis Dulcis (ED) & $30,67^{\mathrm{cd}}$ & $31,75^{\mathrm{b}}$ & 1,30 \\
\hline Leersia Hexandra $(\mathrm{LH})$ & $38,00^{\mathrm{e}}$ & $23,41^{\mathrm{a}}$ & 0,07 \\
\hline
\end{tabular}

Note: Degradation rate/kinetic degredation (kd) of NDF (kd-NDF); ADF (kd-ADF), Hemicellulose (kd-Hemicellulose); and Cellulose (kd-Cellulose)

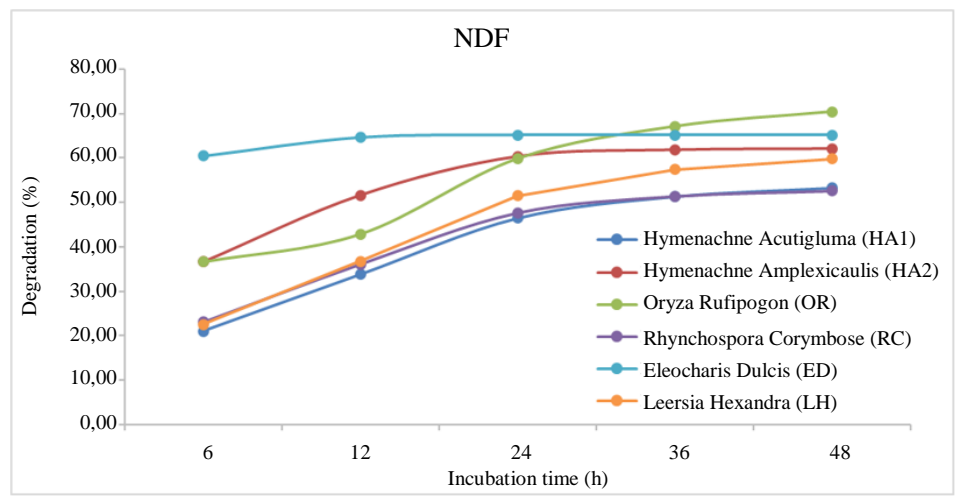

Fig. 1: NDF degradation pattern based on incubation time

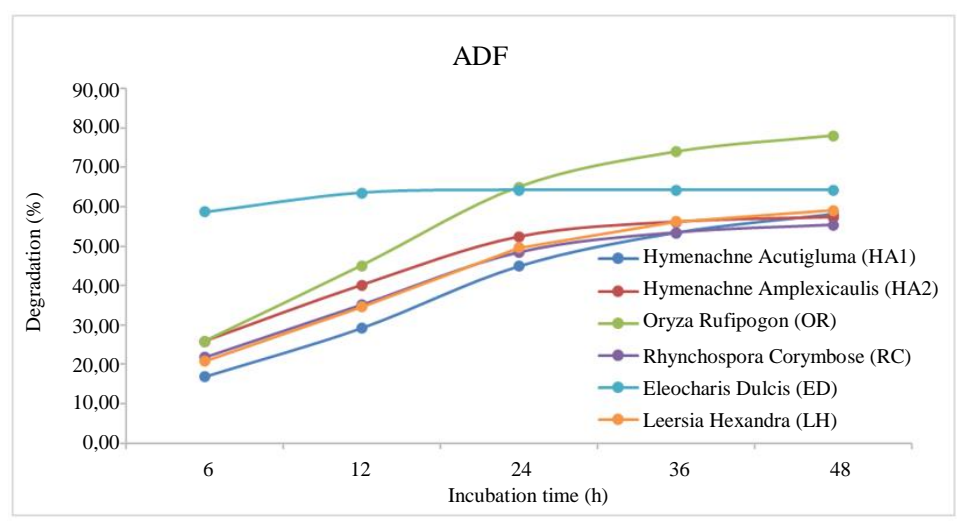

Fig. 2: ADF degradation pattern based on incubation time 


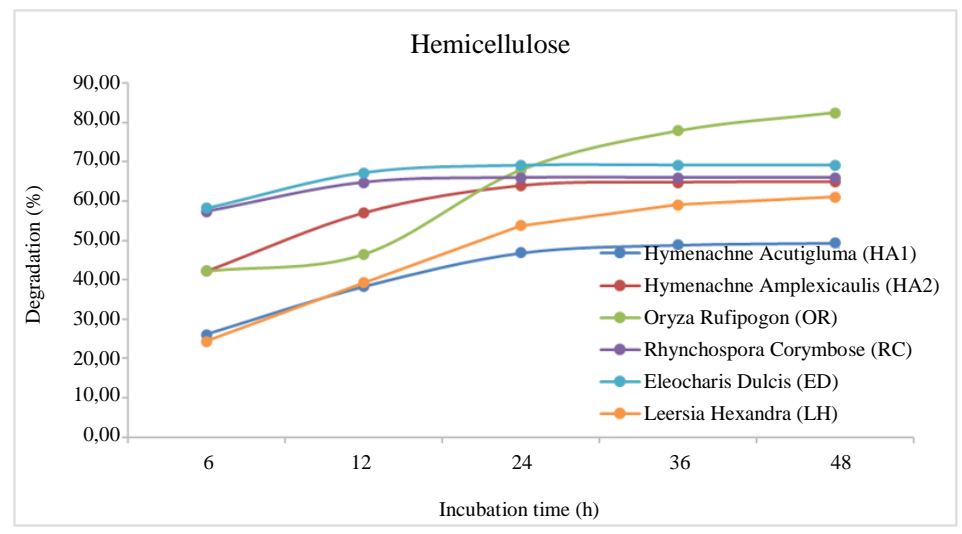

Fig. 3: Hemicellulose degradation pattern based on incubation time

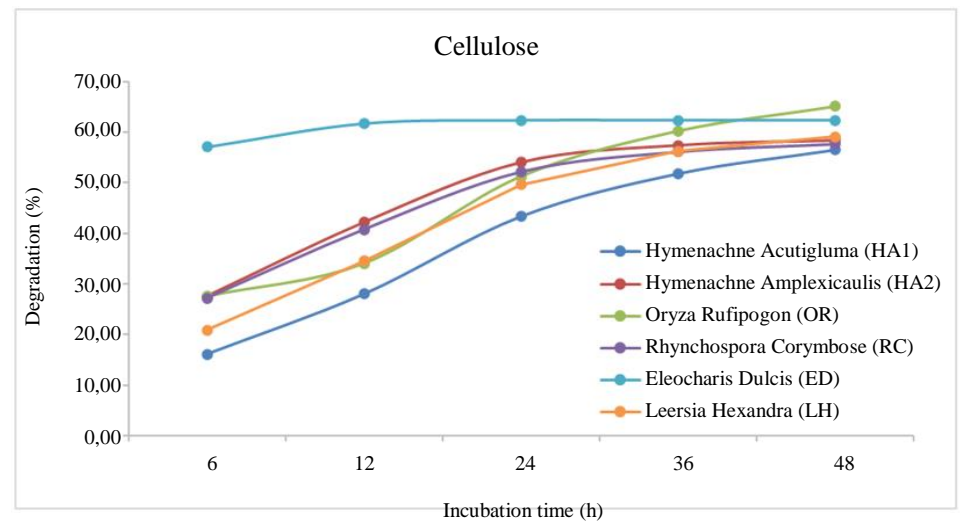

Fig. 4: Cellulose degradation pattern based on incubation time

\section{Discussion}

\section{Total Digestibility}

The hemicellulose and cellulose content strongly was influenced NDF and ADF in a treatment. This correlation can occur because NDF and ADF's main compositions are structural carbohydrate compounds such as hemicellulose and cellulose. NDF compounds have a positive correlation with hemicellulose and ADF compounds with cellulose. The analysis results on HA1, HA2, OR, ED and LH treatments showed the same pattern of the NDF and ADF digestibility values. This pattern occurs because the increased digestibility of hemicellulose and cellulose, affecting NDF and ADF as the main constituents of fiber composition.

The results of the Analysis show that ED grass has the highest NDF and ADF digestibility values compared to other treatments. The high digestibility was thoughted to be the result of high digested hemicellulose and cellulose. This assumption can be proven by comparing the digestibility values in each treatment. Drehmel et al. (2018) reported the increasing the concentration of hemicellulose could increase fiber digestibility. Thereby, Ranathunga et al. (2019) reported no significant difference between low-fiber and high-fiber feeds on the total apparent digestibility NDF and ADF.

Furthermore, the high digestibility of hemicellulose and cellulose in the treated feed was thoughted closely related to the fiber fraction composition in the feed ingredients. Table 1 shows that ED grass has the highest NDF and ADF composition than other treatments, where the high composition is due to the high cellulose content. The cellulose contained in feed ingredients is very good for the development of microorganisms in the rumen. After all, the higher the cellulose content causes an excellent opportunity for feed to extend the residence time in the rumen, which will impact microorganisms in the rumen. It has a longer time to utilize and maximize nutrients in the feed ingredients. According to Fariani (1996), the cut period or harvest period's difference will significantly affect the fiber fraction's composition and digestibility during the in sacco process. The research results that have been carried out on forages and concentrates contained in the fiber show differences in the rate and length of stay in the rumen due to the different types/types of forage used (Krämer et al., 2013). This case was proven again by Asizua et al. (2018) in a different experiment, which reported that the type of forage and 
fiber strongly influences the length of stay of feed in the rumen in the feed ingredients.

Also, ED grass's anatomical structure has a cylindrical and hollow stem inside the stem that resembles a tube and contains cellulose in the stems and leaves of up to $40 \%$ causes ED grass to be very easily digested (Sunardi et al., 2017). Eleocharis Dulcis (ED) is a type of plant/forage found in swamps in various countries and can be classified as a legume crop because ED has tubers and is often categorized as a type of vegetable in various countries (Parr et al., 1996; Ogle et al., 2001). Research on ED grass has overgrown to date, but research is still focused on using tubers and their use as feed for wild poultry, while its use as ruminant animal feed is scarce.

The research results that have been carried out in the last 20 years reveal that ED grass leaves are an auspicious type of swampland vegetation to be used as a protein source concentrate for ruminants because of the high protein content and low fiber content (Pandey and Srivastava, 1991). However, the ED grass contains higher fiber fractions (NDF and ADF) compared to other treatments. The high fraction in these treatments is thought to be due to the high structural carbohydrate fraction in ED grass. Thus, it causes a high total digestibility in the treatment, where it can occur because the cellulose fraction is the digestible fraction in the rumen. Gharechahi et al. (2020) reported that the composition of lignocellulose, or more specifically the cellulose component, can significantly affect the availability of microbes, resulting in changes in the digestibility value of the forage. Furthermore, according to the results of a research report regarding rumen fluid testing of corn straw, it shows that changes in the composition of fiber fractions in the form of hemicellulose and cellulose in the pretreatment resulted in significant changes to the quality of the resulting fermentation (Li et al., 2017).

In this study, it was also found that Kumpai grass such as HA2 and OR did not show a significant difference in the total fiber fraction digestibility. However, it was significantly different when compared to HA1 grass. It was suspected that the HA1 grass contains a higher dry matter content than other treatments and causing the percentage of lignin content very high, resulting in decreased digestibility of hemicellulose and cellulose. In their research, de Carvalho et al. (2017) reported that feeding with different dry matter compositions on several types of topical plants could affect the apparent NDF digestibility value and total digestible nutrients. Furthermore, in the experiment on the treatment of two types of forage with different ages, there were very significant differences in the digestibility of crude protein, crude fiber and fiber fraction, including NDF and ADF resulting from different dry matter content (Sabia et al., 2015).

\section{Fiber Fraction Degradation Pattern}

The incubation analysis results on several types of swamp plantations showed the highest value of fraction a was found in ED grass species. The high value of the dissolved fraction is thought to be closely related to the composition of the NDF content in the feed ingredients, which can be seen from the lower the NDF content, which will result in the lower fraction or fraction that is easily dissolved in the feed ingredients. This result is similar to that reported by + Fariani (1996), Who stated that the different NDF content of various tropical forages could affect the dissolved fraction due to the high cell walls forage growth phase can influence changes in the composition. Corea et al. (2020) reported that differences in NDF and ADF content in vivo feeding experiments showed significant differences between treatments. Furthermore, fraction $b$ or the slowed degradation, the highest value was found in the OR grass treatment. The high value of the fraction was thought to result from the high lignin content contained in the feed ingredients. Lignin, in general, can hinder the process of digestion of feed in the rumen because it is difficult for microbes in the rumen to break down structural carbohydrate compounds contained in feed ingredients. Castro-Montoya and Dickhoefer (2020) stated that various types of forages and legumes found in tropical areas are complicated to digest due to fibers' presence that binds to nitrogen and lignin.

However, the value of fraction $\mathrm{c}$ or the degradation rate of fraction $b$ does not show the same correlation. The highest value was found in the ED treatment, which was thought to be due to the high content of cellulose and low lignin content. Cellulose is a structural carbohydrate that can be digested and binds with lignin in lignocellulosic bonds. The lower the lignin content can weaken the bonds contained in the feed ingredients. According to Nagler et al. (2019) and Guo et al. (2019), the lignocellulose biomass contained in feed ingredients is degraded very slowly, so it requires additional treatment to improve digestibility, including using the help of microorganisms.

The analysis results on each variable, including ADF, hemicellulose and cellulose, showed the same pattern. Overall, the highest fraction value was found in the $\mathrm{LH}$ grass treatment. The high fiber fraction was related to the content and digestibility of hemicellulose. In Table 1, it can be seen that LH grass has the highest hemicellulose content compared to other treatments. The hemicellulose content has a significant role in ADF composition because it was the largest polysaccharide compound in forage. However, the value of cellulose contained in LH grass is still deficient when compared to ED grass. However, the magnitude of this value is part of the ADF and when compared based on the part of the dry matter value, the resulting value is not much different. Another study of hemicellulose was conducted by Drehmel et al. (2018), who reported that the increased hemicellulose 
concentration could increase the fiber fraction's digestibility in the feed.

The value of fraction $b$ or fraction slowly dissolved from the analysis results shows that the highest value is dominated by grass OR on all observed variables. In this case, the cause of the increase was still in the same pattern of NDF digestibility, namely the high lignin content. The high lignin content in forage is a limiting factor in the sugar saccharification process (Oliveira et al., 2020). Furthermore, the fraction $c$ or which reflects the digestibility rate is still dominated by ED grass, which proves that it is fast degrading even though it has a high cellulose content. Therefore, in this study, it is assumed that the material's high digestibility rate is closely related to the anatomical structure of plant cell walls and milling the samples used during the research process. In its publication, the in-Sacco digestibility of a feed ingredient can occur with certain phenomena because it is very dependent on the particle size and bag size used (D’Mello, 2000)

Figure 1 - 4 had been shown the observations of the degradation rate of NDF, ADF, hemicellulose and cellulose at the $6 \mathrm{~h}$ incubation period. Overall, ED grass has the highest digestibility value than other treatments, which then during the incubation period 12-48, the available fiber fraction content has dissolved entirely. There are no nutrients that can be digested so that the graph tends to be flat without any increase. This case was indicated a very high digestion rate in ED grass. The high digestibility rate that occurs is thought to be related to the cell wall structure and sample grinding anatomy. However, the easily dissolved fraction's value is still dominated by LH grass. The high composition of substances that dissolve quickly is due to the high content of hemicellulose in the feed ingredients. High hemicellulose concentrations can affect fiber fraction digestibility in a feed ingredient (Drehmel et al., 2018). Besides that, the role of high fiber digesting bacteria activity in the buffalo rumen is an external factor that causes high digestibility values and rates in this study (Dadheech et al., 2018; Iqbal et al., 2018; Jaglan et al., 2019).

This result was different from other treatments. The degradation rate in the $6 \mathrm{~h}$ incubation period only ranges from $20-40 \%$. It was increased with increasing incubation time, especially in the OR grass treatment. The indicated of the bag's sample, when leaving the bag, is very slow so that the microbes in the rumen have more extended access to digest the fiber fraction in the feed ingredients. According to Kamimura et al. (2019), an experiment carried out on the digestion of lignocellulose using microbial enzymes takes a long time, which lasts between 10-100 days.

\section{Conclusion}

Based on this study, it can be concluded that ED grass has the best fiber digestibility than other types of swamp grass and is very potential for buffalo livestock due to its high degradation rate.

\section{Acknowledgment}

We want to acknowledge The Directorate of Research and Community Services, the Directorate General of Higher Education, Ministry of Research, Technology and Higher Education for the research grant provided, with contract number: 0062/UN9/SB3.LP2M. P.T./2019.

\section{Author's Contributions}

Armina Fariani: Conception, design, Analysis and interpretation of data.

Gatot Muslim: Acquisition of data.

Anggriawan Naidilah Tetra Pratama: Contribute in drafting the article.

Lili Warly: Give final approval of the version to be submitted and any revised version.

\section{Ethics}

An animal feeding experiment was conducted at the experimental station, Department of Animal Science, Faculty of Agriculture, Universitas Sriwijaya. The Buffalos were cared for according to the Animal Welfare Guidelines of the Indonesian Institute of Sciences. The approval of the experiment was granted from Universitas Sriwijaya.

\section{References}

Asizua, D., Mpairwe, D., Kabi, F., Mutetikka, D., Bareeba, F. B., Hvelplund, T., ... \& Madsen, J. (2018). Effects of feeding systems on rumen environment, degradability and passage kinetics in Ankolex Friesian crossbred steers. Livestock Science, 210, 47-54. https://doi.org/10.1016/j.livsci.2018.02.006

Castro-Montoya, J. M., \& Dickhoefer, U. (2020). The nutritional value of tropical legume forages fed to ruminants as affected by their growth habit and fed form: A systematic review. Animal Feed Science and Technology, 114641 https://doi.org/10.1016/j.anifeedsci.2020.114641

Corea, E. E., Castro-Montoya, J., Mendoza, M. V., López, F. M., Martinez, A., Alvarado, M. E., ... \& Dickhoefer, U. (2020). Effect of forage source and dietary rumen-undegradable protein on nutrient use and growth in dairy heifers. Animal Feed Science and Technology, 269, 114658. https://doi.org/10.1016/j.anifeedsci.2020.114658 
D'mello, J. P. F. (2000). Anti-nutritional factors and mycotoxins. Farm animal metabolism and nutrition, 383. https://doi.org/10.1079/9780851993782.0000

Dadheech, T., Shah, R., Pandit, R., Hinsu, A., Chauhan, P. S., Jakhesara, S., ... \& Joshi, C. (2018). Cloning, molecular modeling and characterization of acidic cellulase from buffalo rumen and its applicability in saccharification of lignocellulosic biomass. International Journal of Biological Macromolecules, 113, 73-81. https://doi.org/10.1016/j.ijbiomac.2018.02.100

de Carvalho, G. G. P., Rebouças, R. A., Campos, F. S., Santos, E. M., Araújo, G. G. L., Gois, G. C., ... \& Cirne, L. G. A. (2017). Intake, digestibility, performance and feeding behavior of lambs fed diets containing silages of different tropical forage species. Animal Feed Science and Technology, 228, 140-148. https://doi.org/10.1016/j.anifeedsci.2017.04.006

Drehmel, O. R., Brown-Brandl, T. M., Judy, J. V., Fernando, S. C., Miller, P. S., Hales, K. E., \& Kononoff, P. J. (2018). The influence of fat and hemicellulose on methane production and energy utilization in lactating Jersey cattle. Journal of Dairy Science, 101(9), 7892-7906. https://doi.org/10.3168/jds.2017-13822

Fariani, A. (1996). The Evaluation of Nutritive Value of Forages By In Situ and In Vitro Techniques. Unpublished dissertation in partial fulfillment of the requirements for the degree of Doctor of Philosophy, Tottori University, Tottori Prefecture, Japan.

Fariani, A., \& Evitayani, E. (2008). The Potency of Swamp Grass as Ruminant Feed: Grass production, Carrying Capacity and Fiber Fraction. Journal of the Indonesian Tropical Animal Agriculture, 33(4), 299-304. http://eprints.undip.ac.id/20065/

Gharechahi, J., Vahidi, M. F., Ding, X. Z., Han, J. L., \& Salekdeh, G. H. (2020). Temporal changes in microbial communities attached to forages with different lignocellulosic compositions in cattle rumen. FEMS Microbiology Ecology, 96(6), fiaa 069. https://doi.org/10.1093/femsec/fiaa069

Guo, W., Guo, X. J., Zhu, B. C., Guo, Y. Y., \& Zhou, X. (2019). In situ degradation, ruminal fermentation and the rumen bacterial community of cattle fed corn stover fermented by lignocellulolytic microorganisms. Animal Feed Science and Technology, 248, 10-19. https://doi.org/10.1016/j.anifeedsci.2018.07.007

Iqbal, M. W., Zhang, Q., Yang, Y., Zou, C., Li, L., Liang, X., .. \& Lin, B. (2018). Ruminal fermentation and microbial community differently influenced by four typical subtropical forages in vitro. Animal Nutrition, 4(1), 100-108. https://doi.org/10.1016/j.aninu.2017.10.005
Jaglan, N., Kumar, S., Choudhury, P. K., Tyagi, B., \& Tyagi, A. K. (2019). Isolation, characterization and conjugated linoleic acid production potential of bifidobacterial isolates from ruminal fluid samples of Murrah buffaloes. Anaerobe, 56, 40-45. https://doi.org/10.1016/j.anaerobe.2019.02.001

Kamimura, N., Sakamoto, S., Mitsuda, N., Masai, E., \& Kajita, S. (2019). Advances in microbial lignin degradation and its applications. Current Opinion in Biotechnology, 56, 179-186. https://doi.org/10.1016/j.copbio.2018.11.011

Krämer, M., Lund, P., \& Weisbjerg, M. R. (2013). Rumen passage kinetics of forage-and concentrate-derived fiber in dairy cows. Journal of Dairy Science, 96(5), 3163-3176. https://doi.org/10.3168/jds.2012-6146

Li, F., Zhang, P., Zhang, G., Tang, X., Wang, S., \& Jin, S. (2017). Enhancement of corn stover hydrolysis with rumen fluid pretreatment at different solid contents: Effect, structural changes and enzymes participation. International Biodeterioration and Biodegradation, 119, 405-412. https://doi.org/10.1016/j.ibiod.2016.10.038

Nagler, M., Kozjek, K., Etemadi, M., Insam, H., \& Podmirseg, S. M. (2019). Simple yet effective: microbial and biotechnological benefits of rumen liquid addition to lignocellulose-degrading biogas plants. Journal of Biotechnology, 300, 1-10. https://doi.org/10.1016/j.jbiotec.2019.05.004

Ogle, M. Thi Anh Dao, H., Mulokozi, G., \& Leif Hambraeus, B. (2001). Micronutrient composition and nutritional importance of gathered vegetables in Vietnam. International Journal of Food Sciences and Nutrition, 52(6), 485-499. https://doi.org/10.1080/713671806

Oliveira, D. M., Mota, T. R., Grandis, A., de Morais, G. R., de Lucas, R. C., Polizeli, M. L., ... \& dos Santos, W. D. (2020). Lignin plays a key role in determining biomass recalcitrance in forage grasses. Renewable Energy, 147, 2206-2217. https://doi.org/10.1016/j.renene.2019.10.020

Ørskov, E. R., \& McDonald, I. (1979). The estimation of protein degradability in the rumen from incubation measurements weighted according to rate of passage. The Journal of Agricultural Science, 92(2), 499-503. https://doi.org/10.1017/S0021859600063048

Orskov, E. R., Hovell, F. D., \& Mould, F. T. A. P. (1980). The use of the nylon bag technique for the evaluation of feedstuffs. Tropical Animal Production, 5(3), 195-213. https://www.cabdirect.org/cabdirect/abstract/1981 1421904.

Pandey, V. N., \& Srivastava, A. K. (1991). Yield and nutritional quality of leaf protein concentrate from Eleocharis dulcis (Burm. f.) Hensch. Aquatic botany, 41(4), 369-374. https://doi.org/10.1016/03043770(91)90054-9 
Parr, A. J., Waldron, K. W., Ng, A., \& Parker, M. L. (1996). The wall-bound phenolics of Chinese water chestnut (Eleocharis dulcis). Journal of the Science of Food and Agriculture, 71(4), 501-507. https://doi.org/10.1002/(SICI)10970010(199608)71:4<501::AID-JSFA608>3.0.CO;2-L

Ranathunga, S. D., Kalscheur, K. F., \& Herrick, K. J. (2019). Ruminal fermentation, kinetics and total-tract digestibility of lactating dairy cows fed distillers dried grains with solubles in low-and high-forage diets. Journal of Dairy Science, 102(9), 7980-7996. https://doi.org/10.3168/jds.2018-15771

Rostini, T., \& Jaelani, A. (2015). Pemanfaatan Hijauan Rawa Sebagai Pakan Ternak Pada Kelompok Ternak Banua Raya. Jurnal Pengabdian Al-Ikhlas Universitas Islam Kalimantan Muhammad Arsyad Al Banjary, 1(1). https://ojs.uniskabjm.ac.id/index.php/AIJP/article/view/340
Sabia, E., Claps, S., Napolitano, F., Annicchiarico, G., Bruno, A., Francaviglia, R., ... \& Aleandri, R. (2015). In vivo digestibility of two different forage species inoculated with arbuscular mycorrhiza in Mediterranean red goats. Small Ruminant Research, 123(1), 83-87. https://doi.org/10.1016/j.smallrumres.2014.10.008

Steel, R. G. D., \& Torrie, J. H. (1980) 'Principles and procedures of statistics.' (McGraw-Hill: New York).

Sunardi, S. (2017). Preparation of carboxymethyl cellulose produced from purun tikus (Eleocharis dulcis). In AIP Conference Proceedings 1868, 020008 (2017) (Vol. 1868). https://doi.org/10.1063/1.4995094

Van Soest, P. J. (1988). 'Nutritional ecology of the ruminant: Ruminant metabolism, nutritional strategies, the cellulolytic fermentation and the chemistry of forages and plant fibers.' (Comstock Pub. Associates: Ithaca [N.Y.]) http://www.worldcat.org/oclc/463237934. 